\title{
Robust Estimation by Drone for Surveillance and Bomb Detection using Actuators
}

\author{
S. Dinesh Tharun, P. Siva Kumar
}

\begin{abstract}
This paper provides the estimation through drone for surveillance and bomb diffusion the using actuators. The proposed model is composed that lightweight, portable and user pleasant with reduced complexity. The new glove system is a wi-fi and self-contained machine that's established at the user arm in an effort to control the motion of the robot. The device is not restricted to the variation inside the finger sizes thereby imparting accuracy and comfort for the robotic control. The system is ready with bomb detection and diffusion mechanism. Once the presence of bomb/Metal is detected by using robotic, it initiates commands to the legal officials and the detected bomb can be subtle from a remote area, it linked direct touch with the bomb. Thus the machine provides high security for the existence of the bomb diffusion squad. The proposed device is noticeably useful in the all regions that call for safety and it presents virtual fact in surveillance and diffusion.
\end{abstract}

Index terms: bomb detection; bomb diffusion; high security; virtual fact

\section{INTRODUCTION}

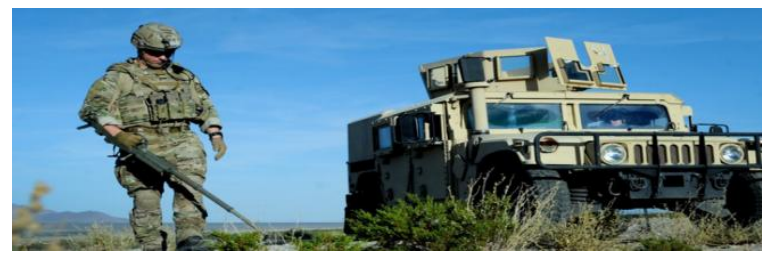

Fig:1.1 Bomb squad monitoring system

A bomb squad monitoring system requires more number of soldiers which are placed to diffuse a bomb and save human life. The wi-fi explosive tool discarding robot which will help to enhance protection of our country from terrorist, suicide bombers and other such activities. The robot that going to made is a command and control robot. This robot takes commands from the user in the form of control signal send performs the required action. The valuable concept at the back of this robot is to offer a line of defense to a bomb clearance squad towards against the existence threatening threat, confronted by means them within the event of an explosion. It offers the squad a secure distance to dispose off a bomb, which generally has to do with his bare hands.

The bomb clearance squads have metal detectors and other gadget for bomb detection and clearance, but they have to threat their lives with the aid of coming near the bomb or some other packet without any protection and Precautions. Our robotic provides an extra layer of

\footnotetext{
Revised Manuscript Received on 14 August, 2019.
}

S. Dinesh Tharun, Department of Electronics and Communication Engineering, Dr. N.G.P. Institute of Technology, Coimbatore, Tamil Nadu, India. (Email: dineshtharun1100@gmail.com)

P. Siva Kumar, Department of Electronics and Communication Engineering, Dr. N.G.P. Institute of Technology, Coimbatore, Tamil Nadu, India. (Email: sivakumar.poruran@gmail.com) protection to the bomb clearance squad by allowing them to take a look at and analyze a suspicious packet before truly drawing near it for clearance. Mobile robots lessen or dispose of a bomb technician's time-on-goal. A robot takes danger out of probably deadly situations and shall we the bomb technician awareness on what to do to an explosive device instead than at the instantaneous chance to existence and limb. Even if a robot cannot attain an item for disruption, it can nevertheless be used to relay information to useful resource in tool and system selection to shifting downrange.

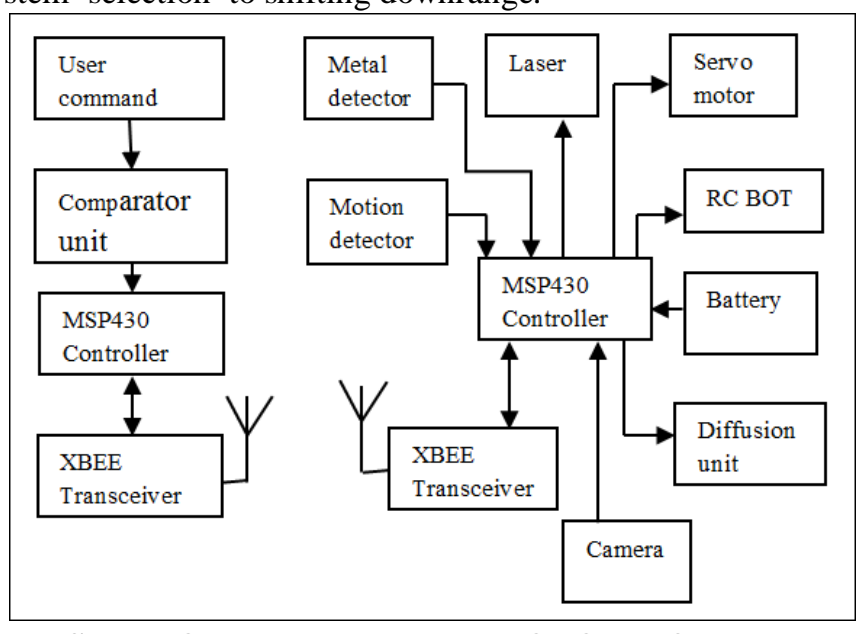

USER MODULE

ROBOT MODULE

Fig: 1.2 Block diagram of proposed work

\section{RELATED WORK}

Abdul Kadir Bin Motaleb [1] proposed a 6 DOF articulated robotic arm established on a moveable base is been advanced to assist bomb disposal squad to dispose bomb appropriately from distance. The complete operation of the robotic may be done wirelessly from a pc.

V. Abilash [2] proposed a wheeled robotic for land mine detection for navy surveying and monitoring motive. The landmine detection robot which can be operated from long distance by using Wi-fi technology. A Global Positioning System sensor is employed, which identifies and the existing place of the robotic. If the metal detector is sensing the landmine and buzzer from generating a warning alarm to the close by stations.

AhsanulHoque[3] proposed a metal detector and GSM module used approximately any bomb underneath the robotic automobile and robotic arm has been installed to pick or drop a few item if wanted. It will provide the 
soldiers statistics about the dangers and situations inside the hostage state of affairs.

AkibJayed Islam [4] proposed two segmented robot palms (3 DOF and three DOF) are established easily connected with an IP digital camera to dispose bomb accurately and easily from distance. It managed wirelessly with its main feature to replace user in bomb disposal unit.

Alejandro Suarez[5] implemented a the dynamic version of the compliant actuator is analyzed and describing the design of the controller for attaining digital variable impedance to external load. The deflection carried out to bimanual force-function manage, to work a stereo vision machine for estimating the deviation of the markers connected to the left/right palms with recognize to their function in an equivalent stiff joint two arm manipulator.

Andrea Manno-Kovacs[6] proposed a computerized picture primarily based target extraction and aperture radar with variety/move-range pictures.By extracting directional and area information as low-degree functions, a saliency map is calculated for the pix and used for purpose detection.

DakshitChalagulla,[7] proposed the gadget of cell robotic systems that had been commanded thru arm positions and it consists of a Wi-Fi digital camera which directs the robot via the user and helps controlling the bomb to be subtle honestly.

DavorinAmbrus[8] implemented detection of buried landmines is a important and most risky part of humanitarian demining (HD) at present, tools for near-in detection of landmines are handheld metal detectors. Discriminating metallic parts of buried

unsafe objectives from normal metal muddle is a very difficult and time-consuming assignment.

Francesca Lunardini [9] implemented a dual DOFs of a robot arm, using muscle synergies extracted from top limb muscle tissue while acting flexion-extension actions of the elbow and shoulder joints inside the horizontal aircraft.

Gang Yang [10] implemented a prototype of clever wearable armband to control a five-finger dexterous robotic and it works a real time application. It provides consolation and softness to accumulating sEMG at any time on the skin surface in keeping with the needs and the real scenario and the positions of electrodes to the forearm will continue to be unchanged in distinct trials with the glove taken off and then re-taken.

Haowei Zhang[11] proposed Multiple-input a couple of output radar technology aiming to the joint of tracking present targets and detecting new threats. The allotted MIMO radar gadget operated inside the centralized mode, where every antenna sends uncooked facts to a common place fusion center and this center controls the complete machine useful resource allocation.

D. Johansen [12] Proposed the inductive tongue manipulate machine for controlling robot/prosthetic arms and palms. The inductive tongue manipulate machine activation unit and located under the preferred sensor on the ITCS MU, which is analysis in the higher palatal vicinity. It handles one part of the sign processing and manages the conversation with the robotic hand .

Jos'e Prado[13] proposed a multi-sensor statistics-fusion technique to discover and localize landmines and unexploded ordnances in a discipline the usage of a couple of cell sensor vendors. It examined greater items buried at the ground, the usage of extraordinary metallic detector arrays and one floor penetrating radar array.

KunjaBihari Swain[14] proposed the intergratedself sustainingvechicle (IAV) is an automatic robotic which has the functionality to reach any nook of the security region without alarming the enemy and it may bomb detection \& demolition, risk detection. It can be controlled both with the Remote - Operator as well as with Self-Assistance.

Luis A. Vázquez[15] proposed a non-stop-time decentralized neural control scheme for trajectory tracking of a ranges of freedom direct energy vertical robotic arm. The continuous of neural control is proven on a robot arm platform, of own format and unknown parameters.

Marco Controzzi,[16] implemented the new multi-draw close hand,to replacement the missing hand and overcome such obstacles and to reduced the complexity of the gadget via designing a 5-fingered anthropomorphic hand based on 3 identical vehicles and on a Geneva pressure transmission.

Maria Makarov[17] proposed a dof controller with anticipation became proposed a couple of-link elastic-joint robots using motor measurements and the $\mathrm{H} 8$ framework became used to solve the constrained with tradeoffs between specifications, consisting a trajectory monitoring, disturbance rejection, and the robustness to unsure or various parameters.

Rakshith[18] proposed a unique and dependable idea on Bomb Disposal Robots and it moves everywhere in the required field and checks for the presence of explosives round it, it reveals the explosive by using the metallic detector and makes the buzzer sound which indicators the bomb squad that an explosive is detected and then Squad tests inside and out of the explosive the camera placed on the robotic.

M. Ramirez-Neria,[19] implemented the tracking trouble of a Flexible- Joint Robotic Arm for a smooth rest to relaxation maneuver averting oscillations with the aid of two manipulate methods with additional quintessential terms, traditional feedback linearization and sliding mode controller.

D.N.S. Ravi kumar [20] proposed the Wireless Bomb Disposal Robot uses a Internet server, at the consumer give up to govern the robotic remotely the usage of Wireless era. The bomb technician controls the robotic the usage of this VNC server.

Robert Hiergeist[21] proposed a Scanning of the under degree by using magnetic gradient sensors is the number one detection approach for unexploded bombs. Using the stray magnetic subject of the resulting magnetic second, the position of the bomb within the ground can be located through scanning the ground degree by one or greater fluxgate gradient sensors.

J. J. Rubio[22] proposed a proportional by-product (PD) manage method for trajectory monitoring of industrial robots and profits are very large. The proportional integral spinoff (PID) anti-vibration manipulate is designed for decreasing the vibration effects inside the displacements of a 
robot manipulator.

SedatDogru [23] proposed a new technique to estimate depth of buried metallic gadgets at unique heights above the soil with a traditional metal detector from the coil's response version to estimate depth.

Siva KarteekBolisetti [24] proposed a target detection architecture is adaptable to interference, that's brought about due to co-lifestyles of sensor nodes inside IoT and adopts smart sensing techniques to reliably come across the presence of the goals. Tania Alauddin[25] proposed a metal detector robot automobile that may be used in metal detection so the robotic rather than human beings may be put to locate a risky object and as a consequence reduce the hazard human loss. The metal detector can detect blanketed metals and the robotic may be managed wirelessly from a distance.

Thuraya Nasser [26] proposed the improvement for the device for use at archaeology web sites to search tough terrain, consequently the want for the development of an impartial and dependable robot which could operate on such terrain and might carry a sensor payload capable of detecting goals with a excessive level of precision and confidence. The robot car includes an automatic running metallic detector circuit that works with Beat Frequency Oscillator principle to alerts the consumer when a target is detected.

TingtingMeng[27] proposed a vibration control and the trajectory monitoring manage of a robot arm gadget with input constraint. By defining composite strength feature, a two loop iterative gaining knowledge of manage law is designed by means of integrating a restricted studying law and a saturated comments regulation.

Wahyono [28] proposed a Image-primarily based surveillance systems are extensively employed closer to safety and protection programs. It is tedious for humans to concurrently take a look at every form of event on several cameras and evaluation of video to hit upon suspicious activities to become aware of unattended gadgets to save you an unexpected twist of fate which include the bombing of a public area.

Yue Wang[29]proposed a programming the commercial robotic for meeting responsibilities by using using parsing the human demonstration into a sequence of assembly skills and compiling the potential to the robotic executables. Using MASD, high accuracy in actual time to extra practical meeting responsibilities beyond natural positional transferring and picking.

Zhou MA,[30]proposed the glove mechanism the person is measured, mapped, and transmitted to the mobile robotic inside the shape of commands throw a wireless community. Conversely, distance records of the items across the robot is collected, processed, and sent again to the glove to generate a digital interplay force to the consumer. Based on the feedback of this virtual pressure, the user can "sense" the technique to an obstacle and subsequently manage the robotic more easily and effectively in an intuitive wayr with natural motions of the finger

\section{Table1. Comparison of surveillance and bomb detection method}

\begin{tabular}{|l|l|l|l|l|l|}
\hline S.no & Author & \multicolumn{1}{c|}{$\begin{array}{c}\text { Implementation } \\
\text { details }\end{array}$} & \multicolumn{1}{c|}{ Remarks } & Advantages & Disadvantages \\
\hline 1 & $\begin{array}{l}\text { Abdul } \\
\text { Kadir } \\
\text { Bin } \\
\text { Motaleb } \\
(2016)\end{array}$ & $\begin{array}{l}\text { DOF articulated robotic arm } \\
\text { established on a moveable and } \\
\text { dispose bomb appropriately } \\
\text { from distance }\end{array}$ & $\begin{array}{l}\text { Bomb disposal robotic } \\
\text { has been superior and } \\
\text { comfy device that allows } \\
\text { you to be useful for } \\
\text { emergency case }\end{array}$ & $\begin{array}{l}\text { Good } \\
\text { Performance }\end{array}$ & $\begin{array}{l}\text { Single channel } \\
\text { communication }\end{array}$ \\
\hline 2 & $\begin{array}{l}\text { Vbilash } \\
(2017)\end{array}$ & $\begin{array}{l}\text { wheeled robot for land mine } \\
\text { detection and a beneficial tool } \\
\text { in for army for Surveying and } \\
\text { monitoring motive }\end{array}$ & $\begin{array}{l}\text { Land-mine detection } \\
\text { robotic may be } \\
\text { operated remotely the } \\
\text { using Wi-fi. A GPS } \\
\text { sensor is hired, which } \\
\text { identifies the present } \\
\text { place of the robot }\end{array}$ & $\begin{array}{l}\text { low cost and } \\
\text { more efficient }\end{array}$ & $\begin{array}{l}\text { weight factor } \\
\text { due to the } \\
\text { overloading of } \\
\text { sensor }\end{array}$ \\
\hline 3 & $\begin{array}{l}\text { Ahsanul } \\
\text { Hoque } \\
(2017)\end{array}$ & $\begin{array}{l}\text { Metal detector and GSM } \\
\text { module used to identifie any } \\
\text { bomb under the robot vehicle } \\
\text { and robot arm has been pick } \\
\text { or drop a few objects }\end{array}$ & $\begin{array}{l}\text { Radio Frequency } \\
\text { modules signals are } \\
\text { utilized in wireless } \\
\text { control device for } \\
\text { transmitting and } \\
\text { receiving wireless } \\
\text { indicators to control and } \\
\text { manage device }\end{array}$ & $\begin{array}{l}\text { To search } \\
\text { invisible } \\
\text { metal stuffs }\end{array}$ & $\begin{array}{l}\text { Range is not so } \\
\text { high }\end{array}$ \\
\hline
\end{tabular}




\begin{tabular}{|c|c|c|c|c|c|}
\hline 4 & $\begin{array}{l}\text { AkibJaye } \\
\text { d Islam } \\
(2017)\end{array}$ & $\begin{array}{l}\text { A two arm bomb disposal } \\
\text { robotic this is designed to help } \\
\text { bomb disposal unit for use in } \\
\text { emergency conditions }\end{array}$ & $\begin{array}{l}\text { Two segmented robotic } \\
\text { hands are transportable } \\
\text { base with an IP camera } \\
\text { to dispose bomb } \\
\text { properly and without } \\
\text { issue from long distance }\end{array}$ & $\begin{array}{l}\text { Performance } \\
\text { is good }\end{array}$ & Cost is high \\
\hline 5 & $\begin{array}{l}\text { Alejandr } \\
\text { o Suarez } \\
(2018)\end{array}$ & $\begin{array}{l}\text { Dual-arm aerial manipulation } \\
\text { development of excessive } \\
\text { overall performance robotic } \\
\text { fingers in pressure / torque/ } \\
\text { impedance manage, to the } \\
\text { aerial platform }\end{array}$ & $\begin{array}{l}\text { A virtual variable } \\
\text { impedance behavior at } \\
\text { joint stage based on the } \\
\text { feedback and manage of } \\
\text { the joint deflection }\end{array}$ & $\begin{array}{l}\text { low weight } \\
\text { and low cost }\end{array}$ & Accuracy is low \\
\hline 6 & $\begin{array}{l}\text { Andrea } \\
\text { Manno- } \\
\text { Kovacs } \\
(2018)\end{array}$ & $\begin{array}{l}\text { Multistatic passive ISAR } \\
\text { based on track extraction and } \\
\text { category technique }\end{array}$ & $\begin{array}{l}\text { The detected targets with } \\
\text { system gaining } \\
\text { knowledge of techniques } \\
\text { and extensively } \\
\text { evaluated on actual } \\
\text { target pictures. }\end{array}$ & Light weight & $\begin{array}{l}\text { Image sequence } \\
\text { processing is } \\
\text { low }\end{array}$ \\
\hline 7 & $\begin{array}{l}\text { DakshitC } \\
\text { halagulla } \\
(2018)\end{array}$ & $\begin{array}{l}\text { Tracking and reputation of } \\
\text { arms that is supposed for use as } \\
\text { human robot interaction } \\
\text { interface }\end{array}$ & $\begin{array}{l}\text { Hand gesture manipulate } \\
\text { machine has been } \\
\text { unfolding the entire } \\
\text { humanity to extensive } \\
\text { range of packages }\end{array}$ & $\begin{array}{l}\text { Wide range } \\
\text { of } \\
\text { applications }\end{array}$ & Cost is high \\
\hline 8 & $\begin{array}{l}\text { Davorin } \\
\text { Ambrus } \\
(2016)\end{array}$ & $\begin{array}{l}\text { Estimation of buried metallic } \\
\text { target using TD EMI } \\
\text { information }\end{array}$ & $\begin{array}{l}\text { To detect a buried metal } \\
\text { target shape the use of } \\
\text { EMI }\end{array}$ & $\begin{array}{l}\text { simple and } \\
\text { reliable } \\
\text { shape-based } \\
\text { target }\end{array}$ & $\begin{array}{l}\text { Limited data } \\
\text { quantity }\end{array}$ \\
\hline 9 & $\begin{array}{l}\text { Francesc } \\
\text { a } \\
\text { Lunardin } \\
\text { i (2015) }\end{array}$ & $\begin{array}{l}\text { Dynamic Protocol manipulate } \\
\text { the robot and Isometric } \\
\text { Protocol controlled the power } \\
\text { interface with } 2 \text { DOFs }\end{array}$ & $\begin{array}{l}\text { Feasibility technique for } \\
\text { software and clinically } \\
\text { orientated multi-DOF } \\
\text { robot control }\end{array}$ & $\begin{array}{l}\text { Reliable } \\
\text { control }\end{array}$ & Cost is high \\
\hline 10 & $\begin{array}{l}\text { Gang } \\
\text { Yang } \\
(2018)\end{array}$ & \begin{tabular}{lr}
\multicolumn{3}{l}{ Machine algorithms have been } \\
discriminate functions of \\
different hand moves, and their \\
performances had been \\
appraised through type \\
complexity & estimating \\
algorithms &
\end{tabular} & $\begin{array}{l}\text { A prototype of smart } \\
\text { wearable armband to } \\
\text { worn a 5-finger } \\
\text { dexterous robot and it } \\
\text { works a actual time } \\
\text { application }\end{array}$ & User friendly & $\begin{array}{l}\text { Accuracy is not } \\
\text { constant }\end{array}$ \\
\hline 11 & $\begin{array}{l}\text { Haowei } \\
\text { Zhang } \\
(2019)\end{array}$ & $\begin{array}{l}\text { Multiple input mulitiple output } \\
\text { radar generation aiming to the } \\
\text { joint of tracking and detecting } \\
\text { new threats }\end{array}$ & $\begin{array}{l}\text { Sensor distribution for } \\
\text { the joint multi-target } \\
\text { tracking and detection in } \\
\text { the distributed MIMO } \\
\text { radar }\end{array}$ & $\begin{array}{l}\text { Uniformly } \\
\text { allocate the } \\
\text { power and } \\
\text { bandwidth } \\
\text { to subarrays }\end{array}$ & $\begin{array}{l}\text { Power\& } \\
\text { bandwidth } \\
\text { limited }\end{array}$ \\
\hline 12 & $\begin{array}{l}\text { D.Johans } \\
\text { en } \\
(2016)\end{array}$ & $\begin{array}{l}\text { Multi-grasp robotic fingers } \\
\text { combining widespread EMG } \\
\text { with the inductive tongue } \\
\text { control device }\end{array}$ & $\begin{array}{l}\text { Inductive tongue control } \\
\text { device for controlling } \\
\text { robotic/prosthetic arms } \\
\text { and hands. }\end{array}$ & $\begin{array}{l}\text { Performance } \\
\text { is high \& } \\
\text { reliable }\end{array}$ & Discomfortable \\
\hline 13 & $\begin{array}{l}\text { Jos'e } \\
\text { Prado } \\
(2015)\end{array}$ & $\begin{array}{l}\text { Multi-sensor and multi- } \\
\text { platform statistics fusion for } \\
\text { buried items detection and } \\
\text { localization }\end{array}$ & $\begin{array}{l}\text { A triple coil metallic } \\
\text { detector in a arm and } \\
\text { buried at the ground, } \\
\text { using MD arrays and } \\
\text { radar(GPR) array }\end{array}$ & Simple & $\begin{array}{l}\text { Not accurate } \\
\text { solution }\end{array}$ \\
\hline
\end{tabular}




\begin{tabular}{|c|c|c|c|c|c|}
\hline 14 & $\begin{array}{l}\text { KunjaBi } \\
\text { hari } \\
\text { Swain } \\
(2017)\end{array}$ & $\begin{array}{l}\text { Integrated Autonomous Vehicle } \\
\text { layout a for bomb detection \& } \\
\text { demolition, risk detection }\end{array}$ & $\begin{array}{l}\text { IAV is an automatic } \\
\text { robotic to reach any part } \\
\text { of the security region } \\
\text { without alarming the } \\
\text { enemy }\end{array}$ & $\begin{array}{l}\text { Reduce } \\
\text { human loss }\end{array}$ & $\begin{array}{l}\text { Control } \\
\text { remotely over } \\
500 \mathrm{~m} \text { range }\end{array}$ \\
\hline 15 & $\begin{array}{l}\text { Luis A. } \\
\text { Vazquez } \\
(2016)\end{array}$ & $\begin{array}{l}\text { The real-time validate of the } \\
\text { time decentralized neural } \\
\text { manipulate scheme developed } \\
\text { for trajectory tracking }\end{array}$ & $\begin{array}{l}\text { Continuous-time } \\
\text { decentralized neural } \\
\text { manage scheme for } \\
\text { trajectory monitoring for } \\
\text { power vertical robotic } \\
\text { arm. }\end{array}$ & $\begin{array}{l}\text { Robotic arms } \\
\text { having more } \\
\text { than two } \\
\text { DOF }\end{array}$ & $\begin{array}{l}\text { Approximate } \\
\text { level is low }\end{array}$ \\
\hline 16 & $\begin{array}{l}\text { Marco } \\
\text { Controzz } \\
\mathrm{i}(2016)\end{array}$ & $\begin{array}{l}\text { A semi actuation of adduction } \\
\text { the thumb and extension the } \\
\text { index, by way of a one actuator }\end{array}$ & $\begin{array}{l}\text { To replacement of a } \\
\text { lacking hand by means } \\
\text { of prosthesis }\end{array}$ & $\begin{array}{l}\text { Reliable and } \\
\text { easy to } \\
\text { maintain }\end{array}$ & $\begin{array}{l}\text { Speed processor } \\
\text { is slow }\end{array}$ \\
\hline 17 & $\begin{array}{l}\text { Maria } \\
\text { Makarov } \\
(2016)\end{array}$ & $\begin{array}{l}\text { A multi joint robots with motor } \\
\text { sensors only the joint elastic } \\
\text { cannot be overload to gain } \\
\text { motion }\end{array}$ & $\begin{array}{l}\text { Combining and layout } \\
\text { for the motion control of } \\
\text { multiple-hyperlink } \\
\text { elastic-joint robots }\end{array}$ & Light weight & Process is slow \\
\hline 18 & $\begin{array}{l}\text { Rakshith } \\
\text { (2017) }\end{array}$ & $\begin{array}{l}\text { The robot controls using } \\
\text { wireless technology and video } \\
\text { show unit. }\end{array}$ & $\begin{array}{l}\text { The robot movement } \\
\text { control and checks the } \\
\text { explosive by the metallic } \\
\text { detector and alert it }\end{array}$ & $\begin{array}{l}\text { Handling the } \\
\text { targeted } \\
\text { objects as per } \\
\text { the given } \\
\text { instructions }\end{array}$ & $\begin{array}{l}\text { Distance of the } \\
\text { range is low }\end{array}$ \\
\hline 19 & $\begin{array}{l}\text { M.Ramir } \\
\text { ez-Neria } \\
(2016)\end{array}$ & $\begin{array}{l}\text { Implemented an quintessential } \\
\text { compensator for comments and } \\
\text { a fundamental compensator } \\
\text { inside the sliding mode }\end{array}$ & $\begin{array}{l}\text { A linearization and } \\
\text { sliding modes techniques } \\
\text { to the monitoring } \\
\text { trajectory problem for a } \\
\text { Robotic Arm joints }\end{array}$ & $\begin{array}{l}\text { Time } \\
\text { consumption } \\
\text { is low }\end{array}$ & $\begin{array}{l}\text { Fast dynamics } \\
\text { Process }\end{array}$ \\
\hline 20 & $\begin{array}{l}\text { D.N.S. } \\
\text { Ravi } \\
\text { kumar } \\
(2017)\end{array}$ & $\begin{array}{l}\text { Wireless bomb disposal Robot } \\
\text { to manipulate the robot } \\
\text { remotely using wireless } \\
\text { generation and controls by } \\
\text { using VNC server }\end{array}$ & $\begin{array}{l}\text { Robotic arm which } \\
\text { allows to diffuse the } \\
\text { bombs and pick the } \\
\text { bomb it desires and } \\
\text { bring it to safer zone. }\end{array}$ & $\begin{array}{l}\text { Control the } \\
\text { robot } \\
\text { remotely }\end{array}$ & $\begin{array}{l}\text { Cannot store the } \\
\text { recording video } \\
\text { footage }\end{array}$ \\
\hline 21 & $\begin{array}{l}\text { Robert } \\
\text { Hiergeist } \\
(2015)\end{array}$ & $\begin{array}{l}\text { Scanning of the ground degree } \\
\text { via magnetic gradient sensors } \\
\text { is the number one detection } \\
\text { technique for unexploded } \\
\text { bombs }\end{array}$ & $\begin{array}{l}\text { Scanning a ground } \\
\text { degree a miles concern } \\
\text { distribution of the flux } \\
\text { gradient for a solenoid } \\
\text { having the equal } \\
\text { dimensions as a regular } \\
\text { UXB can be determined }\end{array}$ & smaller coils & $\begin{array}{l}\text { unchangeable } \\
\text { position }\end{array}$ \\
\hline 22 & $\begin{array}{l}\text { J. J. } \\
\text { Rubio } \\
(2016)\end{array}$ & $\begin{array}{l}\text { Implement a PD control is the } \\
\text { hired technique inside the } \\
\text { trajectory tracking of business } \\
\text { robots. But, the monitoring } \\
\text { errors does now not lower to } \\
\text { zero while the vibration results } \\
\text { are taken into consideration }\end{array}$ & $\begin{array}{l}\text { An anti-vibration } \\
\text { control for lowering the } \\
\text { vibration consequences } \\
\text { in robot manipulator }\end{array}$ & $\begin{array}{l}\text { Performance } \\
\text { is good }\end{array}$ & $\begin{array}{l}\text { Sometimes } \\
\text { vibration level } \\
\text { is increasing }\end{array}$ \\
\hline
\end{tabular}




\begin{tabular}{|c|c|c|c|c|c|}
\hline 23 & $\begin{array}{l}\text { SedatDo } \\
\text { gru } \\
(2018)\end{array}$ & $\begin{array}{l}\text { Vallon VMP3 pulse induction } \\
\text { steel detector was used to } \\
\text { estimate depth of buried } \\
\text { metallic items }\end{array}$ & $\begin{array}{l}\text { Metal detector installed } \\
\text { on a robotic arm is used } \\
\text { and the effectiveness of } \\
\text { the method is proven the } \\
\text { use of splendid styles of } \\
\text { items buried in soil at } \\
\text { numerous depths }\end{array}$ & $\begin{array}{l}\text { Accurate } \\
\text { positioning } \\
\text { and } \\
\text { Measure- } \\
\text { ment }\end{array}$ & $\begin{array}{l}\text { Height of the } \\
\text { metal detector } \\
\text { increases the } \\
\text { signal strength } \\
\text { decreases } \\
\text { rapidly }\end{array}$ \\
\hline 24 & $\begin{array}{l}\text { Siva } \\
\text { KarteekB } \\
\text { olisetti } \\
(2017)\end{array}$ & $\begin{array}{l}\text { Radio Frequency sensing } \\
\text { techniques which offer } \\
\text { excellent advantages over } \\
\text { traditional approach used for } \\
\text { detection applications of IoT }\end{array}$ & $\begin{array}{l}\text { Explore surveillance and } \\
\text { aim detection programs } \\
\text { with radio detection } \\
\text { because the primary } \\
\text { manner of sensing. }\end{array}$ & $\begin{array}{l}\text { No line of } \\
\text { sight required }\end{array}$ & $\begin{array}{l}\text { Low power } \\
\text { consumption }\end{array}$ \\
\hline 25 & $\begin{array}{l}\text { Tania } \\
\text { Alauddin } \\
(2016)\end{array}$ & $\begin{array}{l}\text { A Metal Detector Equipped } \\
\text { wirelss Controlled Robotic } \\
\text { Vehicle utilized in unknown } \\
\text { objects for detection without } \\
\text { setting humans in harm's way }\end{array}$ & $\begin{array}{l}\text { Developed a steel } \\
\text { detector robotic car that } \\
\text { may be used in metallic } \\
\text { detection and land mines } \\
\text { and other risky metal } \\
\text { gadgets }\end{array}$ & $\begin{array}{l}\text { Reduce } \\
\text { human loss }\end{array}$ & $\begin{array}{l}\text { Accuracy and } \\
\text { range are low }\end{array}$ \\
\hline 26 & $\begin{array}{l}\text { Thuraya } \\
\text { Nasser } \\
(2018)\end{array}$ & $\begin{array}{l}\text { The robot automobile includes } \\
\text { an automatic running metal } \\
\text { detector circuit that works with } \\
\text { Beat Frequency Oscillator } \\
\text { principle to indicators the user } \\
\text { whilst a target is detected. }\end{array}$ & $\begin{array}{l}\text { An low-cost a small } \\
\text { floor-based robotic } \\
\text { automobile for } \\
\text { miniaturized metal } \\
\text { detection that use RF } \\
\text { communication to } \\
\text { impact wi-fi verbal } \\
\text { exchange among a } \\
\text { remote controller and the } \\
\text { metal robot automobile }\end{array}$ & $\begin{array}{l}\text { Good } \\
\text { capacity of } \\
\text { detecting } \\
\text { the target. }\end{array}$ & $\begin{array}{l}\text { It can identify } \\
\text { upto } 2 \text { meter }\end{array}$ \\
\hline 27 & $\begin{array}{l}\text { Tingting } \\
\text { Meng } \\
(2017)\end{array}$ & $\begin{array}{l}\text { The input constraint, the dual- } \\
\text { loop ILC law has been designed } \\
\text { to suppress vibration and adjust } \\
\text { the tracking blunders to zero }\end{array}$ & $\begin{array}{l}\text { The vibration manipulate } \\
\text { and the trajectory } \\
\text { monitoring control of a } \\
\text { robot arm system with } \\
\text { enter constraint }\end{array}$ & $\begin{array}{l}\text { Flexible } \\
\text { robotic arm } \\
\text { system }\end{array}$ & $\begin{array}{l}\text { Less } \\
\text { Performance }\end{array}$ \\
\hline 28 & $\begin{array}{l}\text { wahyono } \\
(2016)\end{array}$ & $\begin{array}{l}\text { New approach for detecting } \\
\text { stationary items in video } \\
\text { surveillance structures using a } \\
\text { twin background version.A } \\
\text { collection of twin historical } \\
\text { past difference (SODB) was } \\
\text { built over a positive term }\end{array}$ & $\begin{array}{l}\text { Identify unattended } \\
\text { objects for a video } \\
\text { surveillance systems. }\end{array}$ & User friendly & $\begin{array}{l}\text { Sometimes } \\
\text { failed to detect } \\
\text { object }\end{array}$ \\
\hline 29 & $\begin{array}{l}\text { Yue } \\
\text { Wang } \\
(2018)\end{array}$ & $\begin{array}{l}\text { Programming by means of } \\
\text { demonstration analysis the } \\
\text { robot programming from the } \\
\text { code level to automatic } \\
\text { interface among robot and } \\
\text { human, selling the flexibility of } \\
\text { robotized automation }\end{array}$ & $\begin{array}{l}\text { Task function performs } \\
\text { human skills and } \\
\text { compile robot skills }\end{array}$ & $\begin{array}{l}\text { Enable the } \\
\text { human } \\
\text { assembly } \\
\text { skill to be } \\
\text { translated to } \\
\text { industrial } \\
\text { robots }\end{array}$ & $\begin{array}{l}\text { Limited } \\
\text { computational } \\
\text { resources }\end{array}$ \\
\hline 30 & $\begin{array}{l}\text { Zhou } \\
\text { MA } \\
(2015)\end{array}$ & $\begin{array}{l}\text { analysis the method of a glove } \\
\text { mechanism }\end{array}$ & $\begin{array}{l}\text { RML glove to deal with } \\
\text { each finger and adjust } \\
\text { their movement. }\end{array}$ & Small size & $\begin{array}{l}\text { It design only } \\
\text { for two finger } \\
\text { mechanism }\end{array}$ \\
\hline
\end{tabular}




\section{RESULT AND DISCUSSION}

The different strategies and results are compared by tabulating with the implementation details, advantages and disadvantages of each research work as shown in table 1 .

\section{CONCLUSION}

The survey shown in the table 1 enables in figuring out the Wireless Bomb Clearance Robot has been designed in such a way that it can cater to the needs of the bomb clearance squad, the navy, the police and additionally for the Personnel who cope with radioactive materials. It has limitless packages and can be used in one-of-a-kind environments and scenarios. For example, at one region it may be used with the aid of the bomb clearance squad, whilst at any other example it can be used for dealing with mines

\section{REFERENCES}

1. Abdul Kadir Bin Motaleb, Mohammad Busayeed Hoque(2016) "Bomb disposal Robot" IEEE International Conference on Innovations in Science, Engineering and Technology

2. V. Abilash1 and J. Paul Chandra Kumar2(2017) "Ardunio controlled landmine detection robot”International Conference On Science Technology Engineering and Management (ICONSTEM)

3. Ahsanul Hoque, Md. Baijid Hasan Shorif, Shekh Nuruzzaman, Md. Eftekhar Alam(2017) "Arduino based Battlefield Assistive Robot" IEEE Region 10 Humanitarian Technology Conference (R10-HTC)

4. Akib Jayed Islam, Sadman Shahriar Alam, Khandoker Tanjim Ahammad, Fazllul Karim Nadim, Bithi Barua (2017) "Design, Kinematic andPerformance Evaluation of a Dual Arm Bomb Disposal Robot" International Conference on Electrical Information and Communication Technology (EICT),

5. Alejandro Suarez, Guillermo Heredia , and Anibal Ollero(2018) "Physical-Virtual Impedance Control in Ultralightweight and Compliant Dual-Arm Aerial Manipulators" IEEE Roboticss and automation letters, VOL. 3, NO. 3

6. Andrea Manno-Kovacs, Elisa Giusti, Fabrizio Berizzi,Levente Kov'acs, (2018) "Image Based Robust Target Classification for Passive ISAR" IEEE sensors journal( Volume:19 , Issue:1 , Jan.1, 12019 )

7. Dakshit Chalagulla, Jeevanigi Jayateertha, Tamanneeta Giri, Sailaja. V(2018) "Gesture Controlled Bomb Diffusing Mobile Robot" International Conference on Intelligent Computing and Control Systems

8. Davorin Ambrus,Darko Vasic, Vedran Bilas (2016) “ Robust Estimation of Metal Target Shape Using TimeDomain Electromagnetic Induction Data" IEEE Transactions on Instrumentation and measurement ( Volume: 65 , Issue: 4 , April 2016)

9. Francesca Lunardini, Claudia Casellato, Andrea d'Avella, Terence D Sanger and Alessandra Pedrocchi (2015) "Robustness and reliability of synergy-based myocontrol of a multiple degree of freedom robotic arm" IEEE Transactions on Neural Systems and Rehabilitation Engineering ( Volume: 24 , Issue: 9, Sept. 2016 )

10. Geng Yang, Jia Deng, Gaoyang Pang, Hao Zhang, Jiayi Li, Bin Deng, Zhibo Pang, Juan Xu, Mingzhe Jiang, Pasi Liljeberg, Haibo Xie, Huayong Yang, (2018) “ An IoT enabled stroke rehabilitation system based on smart wearable armband and machine learning" IEEE Journal of Translational Engineering in Health and Medicine ( Volume: 6 )

11. Haowei zhang,Junwei xie, Junpeng shi,Zhaojian zhang,Xiaolong fu (2019) "Sensor Scheduling and Resource Allocation in Distributed MIMO Radar for Joint Target Tracking and Detection" IEEE. Translations and content mining are permitted for academic research only. ( Volume: 7 )

12. D. Johansen, C. Cipriani, D.B. Popović and L.N.S.A. Struijk (2016) "Control of a Robotic Hand Using a Tongue Control System -a Prosthesis Application” IEEE Transactions on Biomedical Engineering(volume:63,Issue:7)

13. Jos'e Prado and Lino Marques (2015) "Multi-sensor and multi-platform data fusion for buried objects detection and localization" IEEE International Conference on Autonomous Robot Systems and Competitions

14. Kunja Bihari Swain, Shubhendu Dash, Suman Sekhar Gouda,(2017) "Raspberry PI Based Integrated Autonomous Vehicle Using LabVIEW" IEEE 3rd International Conference on Sensing, Signal Processing and Security (ICSSS)

15. Luis A. Vázquez, Francisco Jurado, Carlos E. Castañeda, and Victor Santibáñez (2016) "Real-Time Decentralized Neural Control via Backstepping for a Robotic Arm Powered by Industrial Servomotors" IEEE transactions on neural networks and learning sysems Volume: 29, Issue: 2

16. Marco Controzzi, Francesco Clemente, Diego Barone, Alessio Ghionzoli, Christian Cipriani(2016), "The SSSAMyHand: a dexterous lightweight myoelectric hand prosthesis" IEEE Transactions on Neural Systems and Rehabilitation Engineering Volume: 25, Issue: 5

17. Maria Makarov, Mathieu Grossard, Pedro Rodr'1guezAyerbe and Didier Dumur(2016) "Modeling and Preview $\mathrm{H} \infty$ Control Design for Motion Control of Elastic-Joint Robots With Uncertainties" IEEE Translations on industrial electronics, VOL. 63, NO. 10

18. Rakshith, Prithvi Prakash, Sandesh Fernandes(2017) "Real Time Speech - Interactive Bomb Disposal Robot With Face and Object Recognition" International Conference on Electrical, Electronics, Communication, Computer and Optimization Techniques (ICEECCOT)

19. M. Ram'rrez-Neria, G. Ochoa-Ortega, N. LozadaCastillo, M.A. Trujano-Cabrera, J.P.Campos-L'opez, A. Luviano-Ju'arez (2016) "On the Robust Trajectory Tracking Task for Flexible-Joint Robotic Arm with Unmodeled Dynamics" IEEE. Translations and content mining are permitted for academic research only(Volume:4)

20. D.N.S. Ravi kumar, Durgesh kumar (2017) "VNC Server based Robot for MilitaryApplications" IEEE International Conference on Power, Control, Signals and Instrumentation Engineering (ICPCSI-2017)

21. Robert Hiergeist, Rainer Ketzler, Hans Harcken ,Joachim Lüdke , Martin Albrecht, Thomas Brand, Andreas Fischer (2015) "A novel test ground for the equipment qualification of magnetic gradient sensors used for unexploded bomb detection" Journal of Applied Geophysics 112 (2015) 242-248 (Volume 112 )

22. J. J. Rubio, P. Cruz, L. A. Paramo, J. A. Meda, D. Mujica and R. S. Ortigoza (2016) "PID Anti-Vibration Control of a Robotic Arm" IEEE Latin America transactions, VOL. 14, NO. 7

23. Sedat Dogru and Lino Marques(2018) "Estimating Depth of Buried Metallic Objects"IEEE Sensors 
24. Siva Karteek Bolisettiy, Mohammad Patwaryz, AbdelHamid Solimany and Mohamed Abdel Maguid(2017) "RF Sensing Based Target Detector for Smart Sensing within Internet of Things in Harsh Sensing Environments" IEEE. Translations and content mining are permitted for academic research only(Volume:5)

25. Tania Alauddin, Md. Tamzid Islam and Hasan U. Zaman (2016) "Efficient Design of A Metal Detector Equipped Remote-Controlled Robotic Vehicle"International Conference on Microelectronics, Computing and Communications

26. Thuraya Nasser Ibrahim Alrumaih (2018) "The Construction of a Robotic Vehicle Metal Detectoras a Tool for Searching Archaeology Sites" International Conference on Computer Applications \& Information Security

27. Tingting Meng, Wei He (2017) "Iterative Learning Control of a Robotic Arm Experiment Platform with Input Constraint" IEEE Translations on industrial electronics, VOL. , NO. , 2017

28. Wahyono, Alexander Filonenko,Kang-Hyun Jo,(2016) "Unattended Object Identification for Intelligent Surveillance Systems Using Sequence of Dual Background Difference" IEEE Transactions on Industrial Informatics Volume: 12, Issue: 6

29. Yue Wang, Yanmei Jiao, Rong Xiong, Hongsheng Yu, Jiafan Zhang, and Yong Liu(2018) "MASD: A Multimodal Assembly Skill Decoding System for Robot Programming by Demonstration" IEEE transactions on automation science and engineering Volume: 15, Issue: 4

30. Zhou MA ,Pinhas Ben-Tzvi,(2015), "RML Glove-An Exoskeleton Glove Mechanism With Haptics Feedback" IEEE/Asme Transactions on mechatronics, vol. 20, no. 2 